\title{
ОСОБЛИВОСТІ РОЗВИТКУ СТОМАТОЛОГІЧНОЇ ДОПОМОГИ У РОЗВИНЕНИХ КРАЇНАХ ЗАХІДНОЇ ЄВРОПИ ТА ПІВНІЧНОЇ АМЕРИКИ
}

\author{
С. В. Лебедик ${ }^{1}$, С. О. Коноваленко ${ }^{2}$ \\ ${ }^{1}$ Стоматологічна клініка «Без болю», м. Тернопіль \\ ${ }^{2}$ Тернопільський національний медичний університет \\ імені І. Я. Горбачевського МОЗ Украӥни
}

у статті розглянуто основні напрямки розвитку стоматологічної допомоги у розвинених країнах Західної Європи та Північної Америки.

\section{FEATURES OF THE DEVELOPMENT OF DENTAL CARE IN DEVELOPED COUNTRIES OF WESTERN EUROPE AND NORTH AMERICA}

\author{
S. V. Lebedyk ${ }^{1}$, S. O. Konovalenko ${ }^{2}$ \\ ${ }^{1}$ Dental Clinic "Without Pain", Ternopil \\ ${ }^{2}$ I. Horbachevsky Ternopil National Medical University
}

The article discussed the main directions of development of dental care in developed countries of Western Europe and North America.

Вступ. Серед актуальних теоретичних і практично орієнтованих медико-соціальних проблем, що вирішуються на сучасному етапі державою і суспільством, $\epsilon$ стоматологічна допомога. Стоматологічна допомога $є$ однією з найзатребуваніших широкими верствами населення видів медичної допомоги.

У сучасній системі стоматологічної допомоги однією з невирішених проблем є наявність запальних процесів порожнини рота, як наслідок карієсу та його ускладнень, присутності патогенної мікрофлори, зниження місцевого імунітету порожнини рота, комплекс загальносоматичних патологій, що слугує утворенню стійких патогенних штамів мікроорганізмів.

Основна частина. Світова практика надання стоматологічної допомоги населенню розвивається у напрямку залучення пацієнтів до оплати стоматологічних послуг. У більшості європейських країн національні системи стоматологічної допомоги складаються з трьох компонентів: приватного, громадського і страхового. В економічно розвинених країнах світу функціонує дві моделі медичного страхування: бісмарківська і беверіджська. Програми обов'язкового страхування 28 країн світу включають

(c) С. В. Лебедик, С. О. Коноваленко, 2021 надання стоматологічних послуг у різних обсягах, в основному профілактичних, і лікування неускладненого карієсу.

У країнах Західної Європи стали широко впроваджуватися в охорону здоров'я норми гарантії якості, розроблені відповідно до ISO 9001 і 9002 [2, 3]. У розвинених країнах світу стоматологічна служба споживає приблизно 10 \% і більше від усіх фінансових ресурсів системи охорони здоров'я (в Україні менше 2 \%). Стоматологічна допомога в країнах Заходу значною мірою ґрунтується на профілактичній роботі. Вона пов'язана з великими фінансовими витратами.

У США витрати на лікування зубів склали у 2008 р. понад 29 млрд доларів, хвороби зубів зумовили 6,4 млн днів непрацездатності, 14,3 млн днів обмеженої працездатності, що склало в цілому 20,9 млн втрачених робочих днів [4].

У США середня кількість відвідувань лікарів-стоматологів у розрахунку на одну людину зросла з 1,7 у 1991 р. до 2,3 у 2008 р. Залежно від рівня доходу сім'ї цей показник варіював від 1,4 у групі населення 3 найнижчим доходом до 3,3 - з найвищим. Центральною фігурою системи медичного обслуговування у США є приватний лікар. За даними дослідження,

12 ISSN 2411-1597. МЕДСЕСТРИНСТВО. 2021. № 3 
проведеного Каліфорнійським університетом у СанФранциско, близько 80 \% від усіх витрат на систему охорону здоров'я у тій чи іншій формі контролюється саме приватними лікарями. Багато лікарів володіє акціями комерційних лікарень, санаторіїв, діагностичних лабораторій, медичних корпорацій. У США велику увагу приділяють профілактиці стоматологічних захворювань. Так, професія стоматологічного гігієніста виникла у США. Перший навчальний курс зі стоматологічної гігієни був проведений у Бріджпорті у 1913 р. Спеціальність стоматологічного гігієніста була вперше законодавчо затверджена у Нью-Йорку в 1916 р., а перший дозвіл на практику наданий у 1917 р. 3 того часу спеціальність постійно розвивалася. Стоматологічна гігієнічна діяльність на сьогодні займає вагоме місце в сфері охорони здоров'я США. Стоматологічних гігієністів навчають у більш ніж 230 коледжах і університетах. Приблизно 140000 гігієністів працюють за фахом або викладають у вищих навчальних закладах цю дисципліну, беруть участь у наукових дослідженнях. Практично рівне співвідношення між лікарями-стоматологами і стоматологічними гігієністами (близько 130000 лікарів) доводить, що поділ завдань і обов'язків у стоматології в США успішно завершено. На 2000 осіб у США працює один стоматологічний гігієніст, і це наочно демонструє наявність доступу населення до кваліфікованого захисту зубів [5].

Державно-приватне партнерство (ДПП) у США - це закріплена у договірній формі угода між державою і приватною компанією, яка дозволяє останній використовувати державну власність та виконувати функції, які традиційно лежать у сфері відповідальності публічної влади. Термін «державно-приватне партнерство» визначає широкий спектр відносин у діапазоні від простих контрактів, за якими приватна компанія бере на себе певні ризики і погоджується на систему штрафних санкцій, до комплексних, технічно складних проектів, які включають будівництво, модернізацію, експлуатацію об'єктів і управління ними. На практиці взаємодія між зацікавленими сторонами регламентується федеральними та місцевими законодавчими актами, які затверджуються конгресом (якщо мова йде про загальнонаціональні програми) або місцевими законодавчими органами. На думку ряду американських фахівців, «першу скрипку» у ДПП відіграє держава. Інша інтерпретація дПП, яка обговорюється серед американських вчених, полягає у тому, що партнерство означає включення держави до процесу накопичення капіталу і до ринкових від- носин, і тому виникає певна, а в окремих випадках і значна залежність держави від бізнесу [6].

Зараз на території країни успішно діють тисячі проектів дПп між федеральними, муніципальними органами влади та діловим співтовариством. Національна рада з питань державно-приватного партнерства виконує функції розробки загальної стратегії та координації у сфері ДПП. Основними сферами співробітництва $є$ модернізація інфраструктури, розвиток транспортної системи, економічне використання водних ресурсів, утилізація побутових відходів і т. д. На сьогодні, за даними Національної ради державно-приватного партнерства, з 65 середньостатистичних муніципальних сервісних служб 23 функціонує у форматі ДПП (понад 30 \%). ДПП дає можливість місцевій владі зекономити від 20 до 50 \% бюджетних коштів [7].

Систему медичного обслуговування у європейських країнах потрібно розглядати з урахуванням соціальних особливостей, економічної політики держави і підприємництва у найбільших країнах Західної Європи - Німеччині, Франції, Великій Британії, Італії, а також Швеції та Швейцарії. Специфіка європейської моделі у цілому полягає в тому, що повоєнному європейському капіталізму вдалося трансформувати свої політичні, економічні та соціальні інститути в напрямку створення соціально орієнтованого, економічно ефективного варіанта змішаної економіки. Найважливішим принципом європейської моделі $\epsilon$ «демократичний еволюціонізм» - поступове, покрокове вирішення проблем, що виникають в процесі глобальних змін, на основі переговорів і консенсусу. Разом із тим, $\epsilon$ істотні відмінності в окремих європейських країнах [8].

Наприкінці минулого століття відбулись реформи в стоматології у Нідерландах, Великій Британії, Німеччині, Швеції, які були спрямовані на запровадження елементів ринкових відносин у взаємодію між суб'єктами громадської охорони здоров'я [9]. Ця ідеологія відіграла також важливу роль у реформуванні стоматології в Іспанії, Італії, Ізраїлі, Фінляндії, Норвегії, Новій Зеландії [10].

Суть запропонованих нових принципів організації громадського фінансування системи охорони здоров'я зводилася до трьох ключових положень: розмежування функцій покупців і виробників медичних послуг; конкуренції виробників; конкуренції покупців. Наприкінці 80-х років були розроблені норми, які тепер застосовують при сертифікації систем гарантії якості. Гарантія якості, відповідно до 
норм ISO 9001 і 9002, повинна забезпечити відповідну довіру між виробником товарів і послуг та клієнтом $[2,4]$. 3 середини 90-х років ця система у країнах Західної Європи стала широко впроваджуватися у медицину та охорону здоров'я [11].

У Європі в результаті спільної діяльності в ході тривалих дискусій була вироблена основа моделі, яка має назву системи збалансованих показників. Підхід до управління стоматологічними організаціями передбачає виділення як мінімум двох принципових проблем: вдосконалення власне стоматологічної допомоги; вдосконалення системи управління стоматологічною допомогою [11].

Удосконалення стоматологічної допомоги нерозривно пов'язане із запровадженням нових стоматологічних медичних технологій, підвищенням професійної підготовки медичного персоналу стоматологічних організацій та якості стоматологічної допомоги, контрольованої через систему стандартів у стоматології. Удосконалення системи управління стоматологічною допомогою пов'язане із запровадженням прогресивних технологій управління, здатних надати необхідну інформацію для аналізу діяльності стоматологічної організації у чотирьох основних аспектах: «медична допомога», «персонал», «пацієнти» і «фінанси».

Вибір управлінського рішення пов'язаний із вибором інноваційних медичних технологій, які відповідають медико-економічним і соціальним критеріям.

У країнах Західної Європи та Північної Америки за останні три десятиліття різко знизилась поширеність стоматологічних захворювань як серед дитячого, так і дорослого населення. Практично у всіх цих країнах середній рівень КПВ у дитини віком 12 років не перевищує 1,2-1,8.

У Західній Європі взято курс на скорочення втручання держави в економіку, припинення надмірного державного регулювання та передачу ряду повноважень кваліфікованим інститутам підприємницького співтовариства [11]. Реалізація механізму саморегулювання здійснюється за допомогою:

- розробки правил і стандартів підприємницької (професійної) діяльності, які виходять не від держави, а від самих підприємців (професіоналів) і ними ж затверджуються;

- забезпечення належного контролю з боку підприємницьких (професійних) об'єднань за діяльністю своїх членів;

- захисту інтересів учасників підприємницького співтовариства перед третіми особами.
Держава (у даному випадку в особі уповноваженого органу) здійснює загальний нагляд у сфері охорони здоров'я, причому основне навантаження $з$ контролю беруть на себе саме підприємницькі співтовариства, що значно знижує ступінь адміністративного тиску на бізнес і скорочує витрати на утримання державного регулятора. У західних економіках застосовують термін «державно-приватне партнерство» - public-private partnership. ДПП $\epsilon$ якісно новим і ефективним способом залучення інвестицій, оскільки партнерство такого типу не тільки сприяє зростанню економіки, а й розвитку соціально важливої інфраструктури, такої як охорона здоров'я.

Базові характеристики дПП:

- сторонами ДПП є держава і приватний бізнес;

- взаємодія сторін у дПП ґрунтується на офіційній, юридичній основі (на підставі угод, договорів, контрактів тощо);

- взаємодія зазначених сторін має дійсно партнерський, рівноправний характер (тобто в обов'язковому порядку повинен дотримуватися паритету, балансу обопільних інтересів);

- ДПП має чітко виражену публічну, суспільну спрямованість (його головна мета - задоволення державного інтересу);

- у процесі реалізації проектів на основі ДПП консолідуються, об'єднуються активи (ресурси і вклади) сторін;

- фінансові ризики і витрати, а також досягнуті в ДПП результати розподіляються між сторонами у пропорціях відповідно до взаємних домовленостей, зафіксованих в угодах, договорах, контрактах і под. [1].

Інвестиційні моделі спільної участі держави і приватного сектора у сфері охорони здоров'я мають різні форми. В одних країнах основний акцент робиться на інвестиції для створення нових об'єктів інфраструктури, в інших - на підвищення ефективності роботи вже існуючих. Із усього різноманіття моделей державно-приватного партнерства, які існують у світі, можна виділити основні [1].

Франчайзинг - приватна компанія укладає контракт з державним або муніципальним замовником на управління та експлуатацію існуючого об'єкта охорони здоров'я. Приватний партнер інвестує оснащення об'єкта охорони здоров'я, його устаткування і транспортні засоби, забезпечуючи повернення вкладених інвестицій та отримання прибутку за рахунок ефективної експлуатації об'єктів.

Модель «будівництво та отримання у власність для експлуатації на певний час з подальшою пе- 
редачею державі» (build, own, operate, transfer ВООТ) - приватний забудовник експлуатує об'єкт капітального будівництва протягом певного строку, встановленого договором, після закінчення якого права власності на об'єкт повертаються державному або муніципальному замовнику.

Модель «придбання-отримання у власність - зворотний лізинг» (buy, own, lease back - BOLB) - приватний забудовник будує і вводить в експлуатацію об'єкт охорони здоров'я, який потім передає в лізинг державі або муніципалітету. Лізингові платежі протягом встановленого терміну повинні покрити вартість об'єкта і принести прибуток, норма якого встановлюється у контракті. Фактично, ця схема $\epsilon$ «покупкою у розстрочку», за виключенням того, що у міру здійснення виплат лізингових платежів у власність держави або муніципалітету надходить частина об'єкта, пропорційна проміжній сумі виплат.

Модель Alzira (укладення контрактів на будівництво і надання послуг) - приватний забудовник будує, вводить в експлуатацію та експлуатує об'єкт охорони здоров'я, маючи при цьому контракт на надання медичних послуг визначеній контрактом категорії населення [12].

Модель франчайзингу була випробувана у Швеції і включала продаж державної лікарні приватній компанії. у 1991 р. у Швеції приватний сектор був допущений до володіння та управління лікарнями, послугами швидкої допомоги, лабораторіями, що призвело до зниження вартості рентгенівських послуг на 50 \%, лабораторних послуг - на 40 \%, тривалості очікування діагностики та лікування - на $30 \%$.

Австралія має широкий спектр різноманітних моделей, які різняться в окремих штатах. Там після приватизації 50 лікарень витрати на будівництво нових госпіталів впали на 20 \%, а кількість пацієнтів зросла на 30 \%. Австралія стала застосовувати нову модель надання послуг за допомогою механізму ДПП - модель вООТ (built, own, operate, transfer), в рамках якої приватний сектор будує, фінансує, управляє і експлуатує об'єкт інфраструктури, а також володіє правом власності на створений об'єкт до моменту завершення контракту, після чого право власності переходить до держави [6]. Ця модель у Австралії стала домінуючою у реалізації інфраструктурних проектів 90-х років минулого століття.

У Австралії, країні з федеративним устроєм, дПП стартувало у 1980-1990 рр. у регіонах, провінціях і муніципалітетах, адміністрація яких проводила політику державно-приватного партнерства [11]. у 2004 р. в Австралії був створений Національний форум дПп (National Australian PPP forum), який $\epsilon$ основним механізмом координації і співробітництва національних, провінційних і місцевих органів влади щодо реалізації дПП. Національний орган дпп Австралії $\epsilon$ координатором роботи у сфері партнерства не тільки міністерств, а й бізнесу [6].

Приватна фінансова ініціатива (Private Finance Initiative - PFI) у Великій Британії представляє модернізовану концепцію управління державною власністю і $є$ моделлю типу: «дизайн - будівництво - фінансування - експлуатація» (DBFO). Схожі моделі були адаптовані, але у менших масштабах, у Канаді, Португалії, Іспанії та Індії $[6,11,12]$. Подібні моделі дПП були запроваджені в Ірландії для фінансування об'єктів медичної допомоги та закупівлі інфраструктури.

Концесії найпоширеніші у країнах, де партнерство між державою і приватним бізнесом ґрунтується на розробленій законодавчій базі. До таких країн можна віднести Францію, концесійне законодавство якої $\epsilon$ найбільш розвинутим у світі та складається з складної системи правових документів на державному та місцевому рівнях $[1,2,12]$.

Унікальна модель була розроблена у лікарні Alzira в іспанській провінції Валенсія. На основі цієї моделі управління лікарнею здійснюється приватним консорціумом, який несе відповідальність за охорону здоров'я конкретної категорії населення взамін на отримання щорічної оплати на основі нормативу на одну людину [1].

Висновки. Можна констатувати, що світова практика надання стоматологічної допомоги населенню має досвід залучення пацієнтів до оплати стоматологічних послуг і багатий арсенал організаційноекономічних і правових механізмів планування, регулювання та управління діяльністю суб'єктів ринку стоматологічних послуг. Стоматологічна допомога дітям і окремим верствам населення має державну підтримку.

Жодна держава у Європі не забезпечує повністю населення якісною та сучасною стоматологічною допомогою за рахунок бюджету і не здатна виділяти необхідні кошти на сучасне стоматологічне обладнання, технології та матеріали для лікування (профілактики) стоматологічних захворювань у населення.

Один з ефективних організаційно-економічних і правових механізмів у системі інститутів некомерційних медичних організацій (державних, приватних), які не орієнтуються у своїй діяльності на отримання прибутку, реалізується у США. 
У Західній Європі взято курс на скорочення втручання держави в економіку, припинення надмірного державного регулювання та передачу ряду повноважень кваліфікованим інститутам підприємницького співтовариства. Одним з інструментів реалізації даного курсу є «державно-приватне партнерство»якісно новий і ефективний спосіб залучення інвестицій до забезпечення населення стоматологічною допомогою.

До основних особливостей європейської стоматологічної допомоги можна віднести доступність та якість стоматологічної допомоги, інтеграцію стоматологічних і загальних служб охорони здоров'я, використання бригадного методу роботи у стоматологічних закладах, високотехнологічне обладнання стоматологічних кабінетів, проведення профілактичної роботи серед населення. У європейській стоматологічній службі виділено дві принципові проблеми: вдосконалення власне стоматологічної допомоги та вдосконалення системи управління стоматологічною допомогою.

Удосконалення власне стоматологічної медичної допомоги розвивається шляхом:

- підтримки системи стоматологічної допомоги 3 боку держави;

- наявності декількох джерел фінансування стоматологічної допомоги;

- дотримання прав людини в системі охорони здоров'я;

- відповідальності держави (в будь-якій формі) за стоматологічну допомогу соціально незахищеним верствам населення.

Удосконалення системи управління стоматологічною допомогою полягає в розумному поєднанні адміністративного і професійного управління організацією стоматологічної допомоги.

\section{СПИСОК ЛІТЕРАТУРИ}

1. Аввакумов А. А. Проектирование моделей государственно-частного партнерства в реализации инновационной деятельности / А. А. Аввакумов // Государственно-частное партнерство. - 2015. - Т. 2, № 2. - С. 61-74.

2. Викторов В. Н. Развитие стоматологической службы за рубежом (обзор литературы) / В. Н. Викторов, Н. Е. Козлова, Т. Г. Денисова // Здравоохранение Чувашии. 2013. - № 3. - C. 17-21.

3. Policy on Workforce Issues and Delivery of Oral Health Care Services in a Dental Home // Oral Health Policies. 2011. - Vol. 35, No. 6. - P. 26-30.

4. Gordan V. V. Translating research into everyday clinical practice: Lessons learned from a USA dental practice-based research network / V. V. Gordan // Dental Materials. - 2013. Vol. 29, No. 1. - P. 3-9.

5. Determinants of general dentists' decisions to accept capitation payment: a conceptual model and empirical estimates / D. Conrad, R. Lee, P. Milgrom, C. Huebner // Community Dentistry and Oral Epidemiology. - 2010. Vol. 37, No. 3. - P. 189-198.

6. Борщевский Г. А. Государственно-частное партнерство / Г. А. Борщевский. - М. : Юрайт, 2016. - 346 с.

7. Bird D. L. Torres and Ehrlich modern dental assisting / D. L. Bird, D. S. Robinson. Published on May 4, 2018.

8. Community dental clinics: providers' perspectives / B. B. Wallace, M. I. MacEntee, R. Harrison, R. Hole, C. Mitton // Community Dentistry and Oral Epidemiology. - 2013. Vol. 41, No. 3. - P. 193-203.

9. Tickle M. Revolution in the provision of dental services in the UK / M. Tickle // Community Dentistry and Oral Epidemiology. - 2012. - Vol. 40, No. 2. - P. 110-116.

10. Global goals for oral health 2020 // Bull World Health Organ. - 2005. - Vol. 83. - P. 686-693.

11. Сохов С. Т. Стратегия охраны стоматологического здоровья в Европе / С. Т. Сохов, Н. Б. Павлов // Здравоохранение Российской Федерации. - 2010. - № 6. С. 25-29.

12. Хлебников К. В. Государственно-частное партнерство: экономическое содержание и институциональные границы / К. В. Хлебников // Экономические науки. 2015. - № 6. - С. 129-133. 